\title{
Cartografias discursivas: \\ O campo associado e o objeto na constituição do dispositivo
}

\author{
Discursive cartographies: \\ The associated field and the object in the constitution of the device
}

\author{
Bruno FRANCESCHINI \\ Universidade Federal de Catalão (UFCat) \\ https://orcid.org/0000-0003-1661-4835 \\ Cleudemar Alves FERNANDES \\ Universidade Federal de Uberlândia (UFU) \\ https://orcid.org/0000-0002-2644-4705
}

\begin{abstract}
RESUMO: Este artigo tem por objetivo discutir a produção de subjetividade do aluno hiperativo produzida na/pela linguagem, e problematizar os efeitos de verdade dos discursos sobre esse sujeito da educação. Para tanto, a discussão proposta está ancorada teórica e metodologicamente nos estudos de Michel Foucault e toma-se o conceito de dispositivo como norteador para a análise do objeto discursivo eleito. Em uma chave analítica arquegenealógica, discute-se como as instituições escolar e médica produzem discursos sobre quem é esse sujeito da educação, objeto de saberes e poderes que o caracterizam, respectivamente, como um sujeito indisciplinado e doente, que necessita de tratamento especializado, à margem da norma. Os resultados obtidos apontam a subjetivação do aluno hiperativo como um sujeito que necessita de atendimento educacional e médico especializado e confirma a hipótese de que um dispositivo se forma a partir da convergência do objeto e do campo associado para a produção de discursos.
\end{abstract}

PALAVRAS-CHAVE: Análise do Discurso. Michel Foucault. Dispositivo. TDAH. Sujeito da educação.

\begin{abstract}
This article aims to discuss the hyperactive student subjectivity construction through language and problematize as well the effects of truth of the speeches on this subject of education. Therefore, the discussion is anchored in theoretical and methodological studies of Michel Foucault and takes the concept of device as a guide for the analysis of the discursive object. In an archaeo-genealogical key, this article discusses how school and medical institution produce discourses about who this subject of education is, a knowledge-power object that characterize who it is, respectively, as an undisciplined and sick subject, who needs medical treatment, not matching the standards. The results obtained point out that, in addition to the subjectivity of the hyperactive student as a subject that requires specialized educational and medical care, it is also confirmed the hypothesis that a device is formed from the convergence of the object and the associated field with the production of discourses.
\end{abstract}

KEYWORDS: Discourse Analysis. Michel Foucault. Device. ADHD. Subject of education. 


\section{Introdução}

O Transtorno de Déficit de atenção e Hiperatividade (doravante TDAH), tomado como objeto para discussão neste artigo, tem como características principais a agitação e/ou a falta de atenção evidenciadas principalmente em crianças e adolescentes em idade escolar. Considerando que essas características são atestadas por instituições médica e escolar, procuramos descrever e analisar o funcionamento da maquinaria discursiva dessas instâncias produtoras de enunciados sobre o sujeito hiperativo, considerado por nós como um sujeito da educação, objetivado e subjetivado nas referidas práticas discursivas como um sujeito de difícil controle, agitado, inquieto, desatento, dentre outras denominações que o classificam como uma subjetividade à margem da norma.

Com relação à terminologia sujeito da educação, empregamos esse termo, em consonância com Larrosa (1994), como um dos modos de nos referirmos ao aluno hiperativo, por entendermos que as práticas discursivas da Educação e da Saúde são produtoras de discursos sobre esse sujeito que circula no espaço escolar. Nossa ênfase recairá sobre os discursos que objetivam esse sujeito como hiperativo, propendendo a disciplinar e normatizar o hiperativo na escola.

Visando a mostrar como esse sujeito da educação é produzido na/pela linguagem, nosso objeto de análise constitui-se de artigos científicos publicados em periódicos das áreas de Psiquiatria, Neurologia, Farmácia, Psicologia, Pedagogia, que tratam da conceituação, do diagnóstico e das formas de tratamento do TDAH e do sujeito aluno hiperativo. Os artigos selecionados para análise são classificados, segundo a avaliação feita pela CAPES, como Qualis A1 e A2. Teórica e metodologicamente, este estudo toma como conceito principal a noção de dispositivo, de Michel Foucault, e valese também de outros conceitos arrolados, como as práticas de subjetivação, enunciado, campo associado e poder, que são tratados no bojo de uma arquegenealogia de modo a tratarmos do sujeito aluno hiperativo.

Naquilo que diz respeito à arqueologia, procuramos pensar como o saber escolar e a Medicina, considerando a clínica médica, o laboratório e o hospital, espaços institucionalizados, produzem discursos sobre quem é esse sujeito da educação, tomado como objeto de saberes que o caracterizam como um doente, como um sujeito que necessita de tratamento. Já na genealogia, analisamos como o poder atravessa essas instituições e governam os sujeitos - sejam estes profissionais da Educação, da 
Psicologia, da Medicina ou o paciente - que fazem parte desses locais construídos sócio historicamente. Desse modo, considerando o binômio saber-poder, observamos que essa relação implica o funcionamento de práticas discursivas e, consequentemente, a produção e circulação de discursos, bem como as formas de governo do hiperativo pelos sujeitos discursivos que o tomam como objeto de discurso.

Feitos esses apontamentos iniciais, temos por objetivo descrever a formação e a constituição daquilo que chamamos de Dispositivo de TDAH. Assim, investigamos a dupla dimensão discursiva desse dispositivo, sendo essa duplicidade composta por dois discursos oriundos do saber médico: a Psiquiatria e a Neurologia, ambos operando com a ordem do olhar. Ou seja, no processo de investigação de uma enfermidade, tanto o psiquiatra quanto o neurologista estão atentos ao comportamento e ao cérebro do doente, respectivamente. A duplicidade de objetos que se prestam ao olhar médico nesse campo científico opera um sistema de isotopia e de isomorfismo (FOUCAULT, 2009) nas grades de saber-poder.

No domínio desse funcionamento discursivo, descreveremos como o objeto e o campo associado, elementos da função enunciativa, são os motores que dão forma a esse dispositivo de TDAH, às condições de possibilidade dos discursos, e, em decorrência disso, como fazem funcionar as práticas discursivas que objetivam e subjetivam o sujeito hiperativo, além das especificidades isotópicas e isomórficas inerentes a este dispositivo.

\section{Cartografias discursivas: as condições de possibilidade do dispositivo de TDAH}

Nossa reflexão sobre o acontecimento discursivo que produziu a emergência do DSM $^{1}$ como um enunciado e possibilitou a circulação do discurso sobre o TDAH reside no fato de que a compreensão de acontecimento trata daquilo que foi dito e que é tomado como algo novo, sobre o qual é preciso compreender sua existência singular, como a clássica questão formulada por Foucault (2009, p. 31) "que singular existência é esta que vem à tona no que se diz e em nenhuma outra parte?’. No trabalho de descrição e análise dos discursos sobre o TDAH, procuramos expor o que possibilitou a

1 Manual Diagnóstico e Estatístico de Transtornos Mentais (Diagnostic and Statistical Manual of Mental Disorders - DSM). Informações disponíveis em: https://www.psychiatry.org/psychiatrists/practice/dsm. Acesso em 10 de julho de 2020. 
circulação de enunciados sobre esse objeto, tendo em vista que "o novo não está no que é dito, mas no acontecimento de sua volta" (FOUCAULT, 2008, p. 26).

Nessa empreitada arqueológica, descrevemos e analisamos as condições de possibilidade dos discursos sobre o TDAH, as regras de formação dos enunciados, a regularidade e a singularidade destes. Pautados em Foucault (2009), tratamos dos enunciados a serem analisados - os DSMs - como acontecimentos discursivos de diferentes ordens, em especial pela relação estabelecida com o corpo, tendo em vista que o tomamos como superfície de inscrição de discursos, na análise dos movimentos de objetivação e de subjetivação das diferentes práticas que discorrem na atualidade sobre o TDAH e sobre o hiperativo.

De acordo com a Associação Americana de Psiquiatria (APA), a formulação do primeiro volume foi precedida da necessidade de classificação das doenças mentais e também da variedade de sistemas classificatórios, uma vez que alguns consideravam aspectos orgânicos, etiológicos e fenomenológicos. Em 1917, a Comissão de Higiene Mental (National Comission on Mental Hygiene) e a Associação Médica-Psicológica Americana (American Medico-Psychological Association) realizaram um censo, de modo a verificar e classificar as doenças mentais nos EUA.

Em conjunto com a Academia de Medicina de Nova Iorque (New York Academy of Medicine), houve, então, o desenvolvimento de uma nomenclatura que poderia ser utilizada em todo o país e seria incorporada à primeira edição de um guiapadrão com as nomenclaturas das doenças psiquiátricas (American Medical Association's Standard Classified Nomenclature of Disease), e em 1921 foi criada a Associação Americana de Psiquiatria (APA).

Após a criação da APA, no período após a Segunda Guerra Mundial, surgiu a necessidade advinda do exército norte-americano de se desenvolver a nomenclatura, de modo a lidar com os veteranos de guerra que apresentavam distúrbios psicológicos e psiquiátricos de diferentes ordens. Concomitantemente, foi publicado o sexto volume do CID (Classificação Internacional de Doenças), no qual foi incluída uma seção destinada às doenças mentais. Após o desenvolvimento dessa seção, a APA publicou, em 1952, o primeiro volume do DSM, que tinha por objetivo o uso clínico. Assim, o corpo hiperativo começa a ser delineado na emergência dos Manuais Diagnósticos, os quais analisamos sob a perspectiva foucaultiana com vistas a descrever a constituição das unidades do discurso, das séries enunciativas estabelecidas e das relações entre os discursos, conforme encontramos na arqueologia foucaultiana. 
Para explicarmos a leitura dos DSMs como um integrante de um arquivo, recorremos a Foucault (2009), que, com base nas teses da Nova História, considera a descontinuidade, o descentramento do sujeito e a problematização do documento como norte para suas análises. Nesse movimento, procuramos estabelecer a pertinência dos diversos acontecimentos discursivos que possibilitaram a emergência do DSM como um acontecimento discursivo, considerando o estabelecimento de séries e os jogos enunciativos entre os sujeitos que falam nesses enunciados.

Foucault (2014) explica que o acontecimento discursivo é múltiplo e que compreende instituições, questões políticas, jurídicas e sociais. Assim, neste tópico, descrevemos os Manuais com relação a essa gama de elementos que balizam a produção e circulação dos discursos da Psiquiatria. No trabalho de descrição dos enunciados, analisamos a dispersão de elementos que estão nas condições de possibilidade do discurso, bem como a

multiplicidade que podemos reconhecer e caracterizar como acontecimento discursivo na medida em que tem como efeito definir: o lugar e o papel de um tipo de discurso, a qualificação daquele que deve fazê-lo, o âmbito de objetos ao qual se dirige, o tipo de enunciados que ocasiona. (FOUCAULT, 2014, p. 175)

No domínio das condições de possibilidade, considerando a escola como uma instituição de poder, analisamos os discursos que tratam do papel da moral nesse espaço institucional e, consequentemente, na prática discursiva escolar, como um elemento discursivo que possibilita o discurso de patologização do TDAH e do hiperativo, como exemplificado neste enunciado retirado do arquivo da pesquisa:

\begin{abstract}
A escola deveria ser um empreendimento puramente moral. Esse exemplo apenas nos prova que, historicamente, na prática educacional, institucional e terapêutica, as técnicas morais de controle da natureza nunca foram realmente banidas. $\mathrm{O}$ treino moral da vontade e da atenção era o mais enfatizado
\end{abstract}

Para a análise desse enunciado, com o objetivo de desenvolver nossas reflexões sobre a marginalização do hiperativo na escola e da produção e circulação de discursos que concebem o TDAH como algo patológico, destacamos as seguintes marcas linguístico-discursivas: "empreendimento puramente moral", "técnicas morais de controle da natureza" e "treino moral da vontade e da atenção". Pautados em Foucault (2010), trabalhamos a materialidade desse enunciado com o objetivo de refletir sobre a emergência das leis, no caso, os DSM, e a correção do indivíduo que escapa dessas leis: o hiperativo. 
Consoante com Foucault (2011), que discorre sobre a anomalia e os três elementos que constituíram esse domínio: o monstro humano, o indivíduo a ser corrigido e a criança masturbadora, observamos que o hiperativo é considerado um infrator das leis morais da escola, esse sujeito é a anomalia nessa instituição, porque ele viola as leis, como explica Foucault (2011, p. 47):

O que define o monstro é o fato de que ele constitui, em sua existência mesma e em sua forma, não apenas uma violação das leis da sociedade, mas uma violação das leis da natureza. Ele é, num registro duplo, infração às leis em sua existência mesma.

Analisamos o hiperativo como um sujeito duplamente infrator ao não corresponder ao comportamento esperado na escola - leis da sociedade - e também por apresentar, em suas questões orgânicas e fisiológicas, uma violação das leis da natureza, sendo comparado, assim, ao monstro. Além dessas questões, o hiperativo assemelha-se ao indivíduo a ser corrigido, porque ele é paradoxalmente incorrigível, tendo em vista que há uma gama de instituições e de práticas que procuram corrigi-lo.

Ao elaborarmos nossas reflexões acerca da constituição de um dispositivo, vemos as linhas de um saber médico começarem a ser delineadas a nossa frente, bem como os elementos de ordem sócio histórica que, em consonância com o saber médico, formam o que Foucault (1977b) concebe por dispositivo. Nas palavras de Dreyfus \& Rabinow (2010, p. 161), “a partir desses componentes díspares, tentamos estabelecer um conjunto de relações flexíveis, reunindo-as em um único aparelho, de modo a isolar um problema histórico específico".

Portanto, os "elementos díspares" que discutimos neste texto dizem respeito às demandas sociais e históricas, externas ao saber médico e que constituem um "problema histórico específico": o Transtorno de Déficit de Atenção e Hiperatividade - TDAH. Procuramos, então, discutir como essa urgência possibilitou a constituição de um saber médico, a partir da formação de um saber psiquiátrico, sobre o que é o TDAH ao traçarmos os diagramas que compõem esse dispositivo, uma vez que o diagrama

é intersocial [...]. Ele nunca age para representar um mundo preexistente, ele produz um novo tipo de realidade, um novo modelo de verdade. Não é sujeito da história nem a supera. Faz a história desfazendo as realidades e as significações anteriores, formando um número equivalente de pontos de emergência ou de criatividade, de conjunções inesperadas, de improváveis continuuns. Ele duplica a história com um devir. (DELEUZE, 1988, p. 45).

A psiquiatrização da infância é uma das formas iniciais de se normatizar os comportamentos, e um dos modos pelos quais esse processo tem início é no seio 
familiar, por meio da ordem do olhar, ou seja, a criança está sempre exposta a um regime de visibilidade daqueles que dela cuidam. Nesse ínterim, o discurso da Psiquiatria também faz parte desse movimento, uma espécie de moto-contínuo em que ocorre a formação de um saber sobre a criança tendo em vista seu comportamento. E

esse discurso de verdade [...] e essa relação com a família se amparam
mutuamente, se apoiam um no outro e vão, finalmente, dar lugar a certo
discurso psiquiátrico, que se dará como discurso de verdade e que terá
essencialmente por objeto, por alvo, por campo de referência, a família, os
personagens familiares, os processos familiares (FOUCAULT, 2006, p. 118).

Portanto, o processo de patologização dos comportamentos da infância e da adolescência perpassa tanto a instituição familiar quanto a psiquiátrica de modo a atentar ao diagnóstico do desenvolvimento do infante. Sobre esse movimento, como explica Foucault (2006, p. 154), "o olho familiar tornou-se olhar psiquiátrico ou, em todo caso, olhar psicopatológico, olhar psicológico. A vigilância da criança tornou-se uma vigilância em forma de decisão sobre o normal e o anormal".

Observamos que a ordem do olhar é um dos principais componentes do dispositivo, porque é por meio das linhas de visibilidade que os sujeitos discursivos em diversas instâncias podem enunciar seus discursos. Considerando a posição de onde o sujeito fala, há as implicações das relações de saber-poder, até mesmo porque os sujeitos que falam estão compreendidos nesse regime de visibilidade. Como expõe Deleuze (1988, p. 66), “a condição à qual a visibilidade se refere não é, entretanto, a maneira de ver de um sujeito: o próprio sujeito que vê é um lugar na visibilidade".

No processo de construção discursiva do TDAH, verificamos, portanto, que os sujeitos que falam sobre esse objeto estão inscritos em dispositivos múltiplos e díspares, mas estabelecem relações entre si. Chegamos a essa observação quando da delimitação dos planos discursivos a respeito das linhas que compõem o dispositivo, conforme teorizado por Deleuze (1996), a saber: visibilidade, força, enunciação e subjetivação.

Chegamos a essa discussão, também, quando da observação e descrição de como se formam os saberes sobre o que é o TDAH e quem é o sujeito hiperativo e ao depararmo-nos com os discursos da Psiquiatria e da Neurologia, posto que são dois discursos pertencentes a uma mesma formação discursiva e têm um objeto em comum: o cérebro. No entanto, o trabalho com esse objeto para esses dois campos é diferente, haja vista que, para a Psiquiatria, o interesse recai sobre os comportamentos, enquanto, para a Neurologia, a atenção está voltada aos aspectos orgânicos cerebrais. 
Desse modo, observamos um imbricamento da Psiquiatria e da Neurologia quando explicam o que é o TDAH ao passo que, mais uma vez, ocorre um processo de normatização do Transtorno. Foucault (2010) comenta sobre o desenvolvimento da Neuropsiquiatria enquanto um novo campo científico que se abre para tratar de questões orgânicas e comportamentais, ou, nos dizeres do autor, "sintomatológicas". Essa junção é uma "ancoragem profunda da psiquiatria na medicina do corpo, possibilidade de uma somatização não simplesmente formal no nível do discurso, mas de uma somatização essencial da doença mental" (FOUCAULT, 2010, p. 138).

Como explica Foucault (2006), o psiquiatra é o sujeito discursivo autorizado a instaurar a doença. Nessa perspectiva, observamos que, na junção desses dois planos discursivos, o saber a respeito do corpo neurológico, do cérebro doente é um elemento central, mas não definidor do que é o TDAH, ou outras desordens psiquiátricas, o que está em jogo são os comportamentos. Ao pensarmos nas linhas de força que compõem o dispositivo dos sujeitos na ordem do discurso psiquiátrico, observamos que, “certamente, nessa máquina ninguém ocupa o mesmo lugar. Certos lugares são preponderantes e permitem produzir efeitos de supremacia" (FOUCAULT, 1977a, p. 117).

Portanto, finalizamos este tópico com a reflexão sobre o funcionamento do arquivo e do enunciado na formação do Dispositivo de TDAH, tendo em vista a importância do arquivo, segundo o regime discursivo que faz circular aquilo que pode ser dito. Como argumentam Guilhaumou e Maldidier (1997, p. 164), “o arquivo não é um simples documento no qual se encontram referências; ele permite uma leitura que traz à tona dispositivos e configurações significantes".

Do primeiro esboço cartográfico aqui proposto, analisamos os Manuais com foco nas linhas de visibilidade e de enunciação, conforme conceituado por Deleuze (1996), e essas linhas compreendem diferentes aspectos em uma mesma prática discursiva, como a diferenciação do processo de objetivação do cérebro para o psiquiatra e para o neurologista. Portanto, no interior do Dispositivo de TDAH, quando da cartografia, observamos como esses discursos agem sobre o corpo do hiperativo em suas especificidades e, com base no mapeamento dos elementos relacionados a cada prática, analisamos os modos pelos quais a produtividade do poder se exerce.

Observamos, desse modo, como o TDAH e o corpo hiperativo são apropriados como objeto da prática discursiva médica e como esta se desdobra em seu campo discursivo e faz funcionar o dispositivo disciplinar da Medicina em conjunto com o 
dispositivo escolar. No próximo tópico, mostraremos o que possibilitou a formação do Dispositivo de TDAH em suas especificidades, como o objeto TDAH e o campo associado desse objeto são os motores do dispositivo e das diferentes práticas que se avizinham para constituição desse objeto sob diferentes perspectivas, mobilizando, dentro de uma mesma prática discursiva e em práticas díspares, diferentes sujeitos.

Por fim, ao convocarmos o arquivo para a descrição das condições de possibilidade do Dispositivo de TDAH, julgamos necessário, para o momento seguinte, descrever o exercício da função enunciativa dos enunciados que circulam nesse campo enunciativo e das práticas discursivas da escola e da Medicina e suas especificidades sobre o TDAH e o corpo hiperativo.

\section{0 campo associado e o objeto: a produtividade de ambos para o dispositivo}

A constituição do TDAH enquanto objeto para análise discursiva se dá pela convergência dos discursos provenientes dos campos da educação e da Medicina e pela relação estabelecida entre os diferentes domínios do discurso, para que se tornasse possível enunciar e constituir esse objeto. Como explica Foucault (2009, p. 102-103), “em compensação, o que se pode definir como correlato do enunciado é um conjunto de domínios em que tais objetos podem aparecer e em que tais relações podem ser assinaladas"

Nesse movimento discursivo, consideramos, também, que o campo associado é importante para a constituição do objeto, sendo que a hipótese que levantamos para a existência de um dispositivo é a de que o campo associado e o objeto são os elementos fundadores para o funcionamento do dispositivo, porquanto, dada a dispersão de sujeitos e de suportes, a organização da regularidade enunciativa converge para o objeto, que organiza a sequência de enunciados, e propaga-se para o campo associado, no qual podemos observar a reverberação desses enunciados e dos sujeitos que falam.

Um dos principais elementos observados diz respeito à possibilidade de se encontrar artigos semelhantes e ampliar o campo discursivo por meio do hiperlink. Com relação ao funcionamento digital da revista eletrônica, trabalharemos, adiante, a constituição do objeto TDAH pelo funcionamento discursivo do hiperlink no âmbito do domínio associado. Como explica Koch (2005), a leitura e a produção de sentidos no 
domínio virtual, por meio da utilização de links, indicam ao leitor os caminhos a serem seguidos para que a leitura seja compreensível.

Isso posto, apresentamos a série enunciativa recortada do arquivo da pesquisa para a descrição e interpretação das práticas discursivas da Educação e da Saúde e mostraremos como elas constituem o Dispositivo de TDAH:

Enunciado 1) ${ }^{2}$

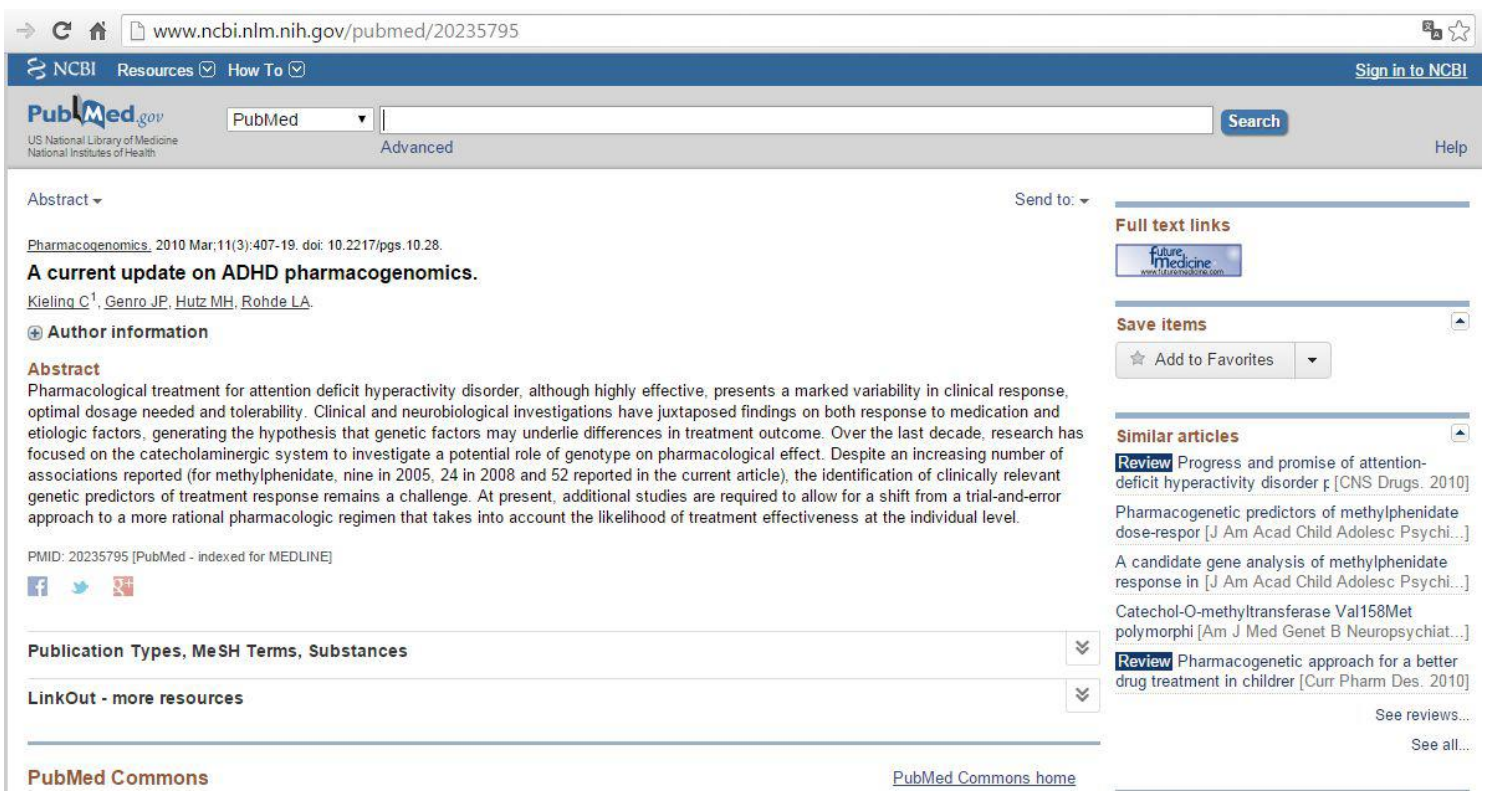

Enunciado 2) ${ }^{3}$

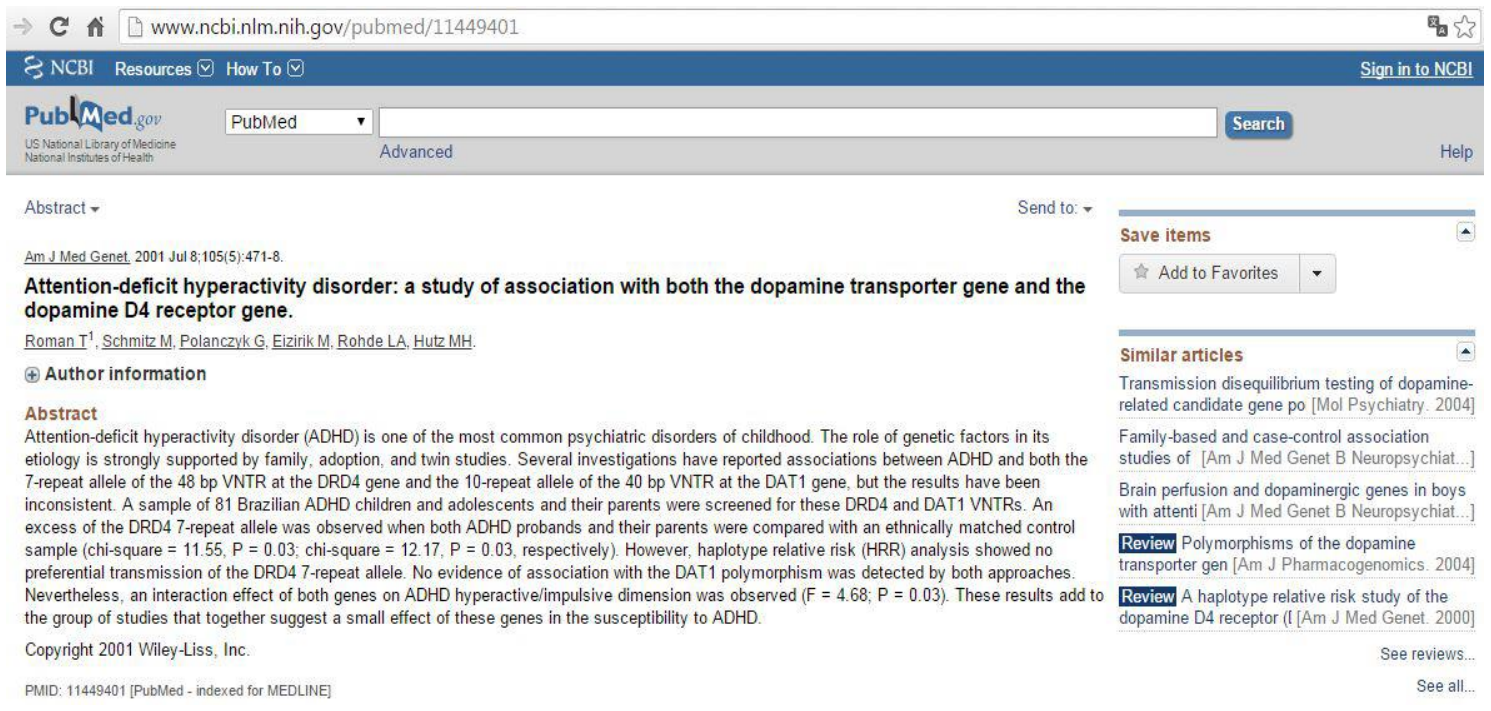

Enunciado 3) ${ }^{4}$

2 Disponível em: https://www.ncbi.nlm.nih.gov/pubmed/20235795. Acesso em: 10 jun. 2014.

3 Disponível em: https://www.ncbi.nlm.nih.gov/pubmed/11449401. Acesso em: 20 ago. 2015

4 Disponível em: https://genomemedicine.biomedcentral.com/articles/10.1186/gm107. Acesso em: 10 jun. 2014. 


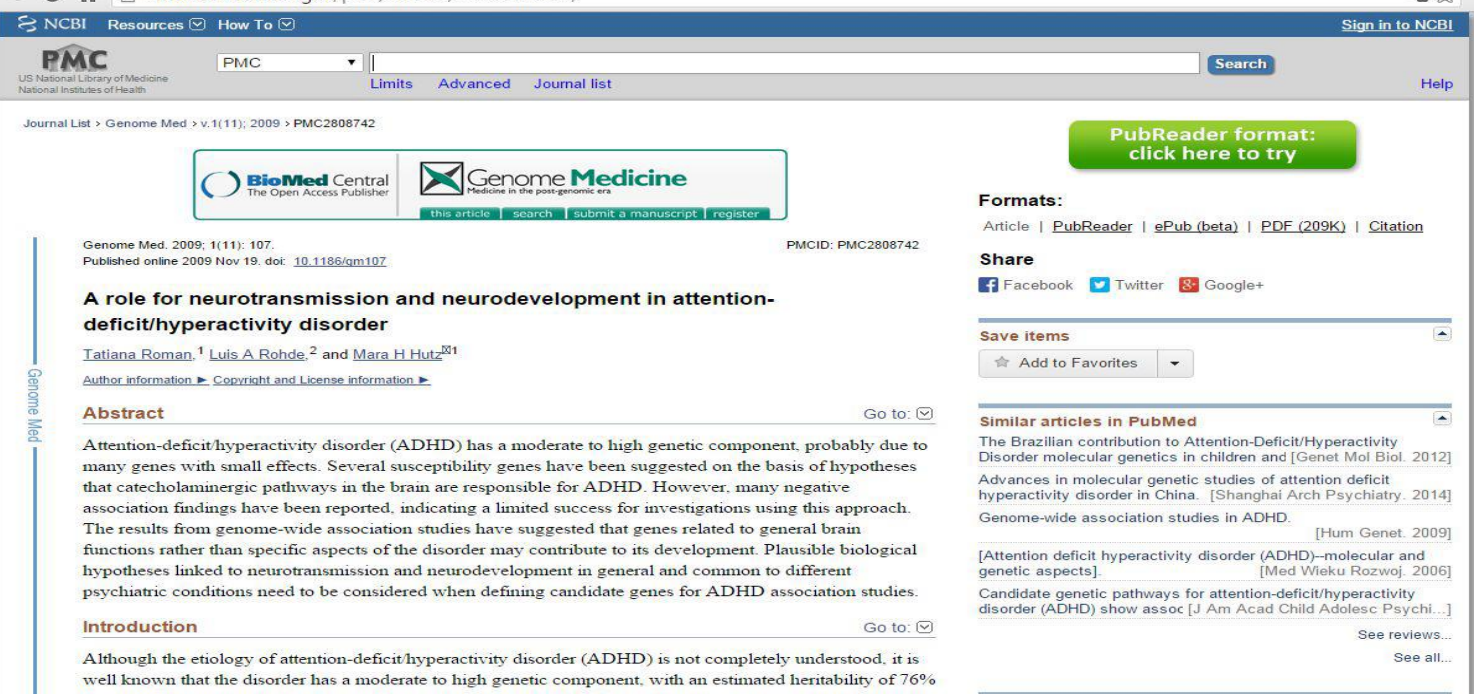

Enunciado 4) ${ }^{5}$

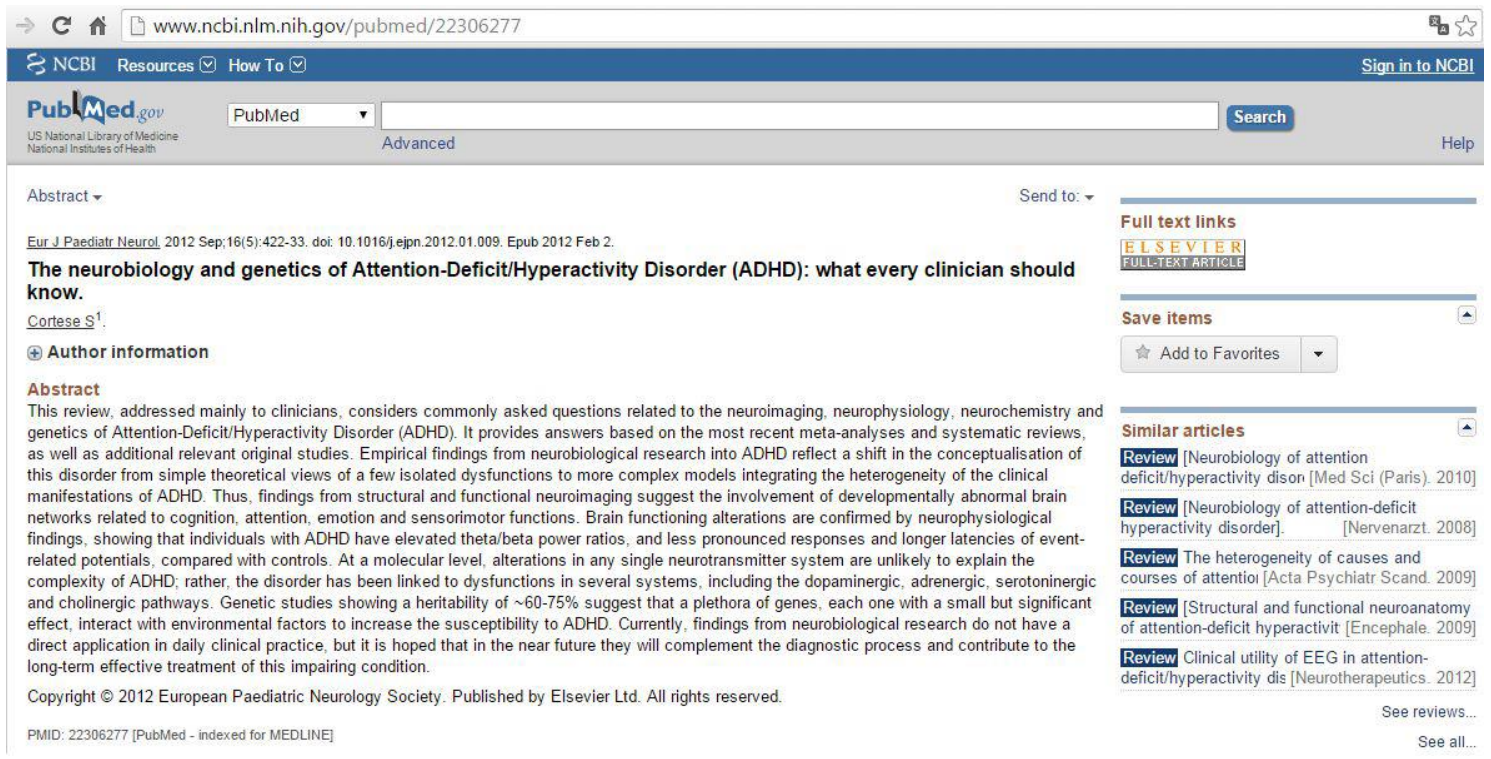

5 Disponível em: https://www.ncbi.nlm.nih.gov/pubmed/22306277. Acesso em: 20 ago. 2015. 


\section{Enunciado 5) ${ }^{6}$}

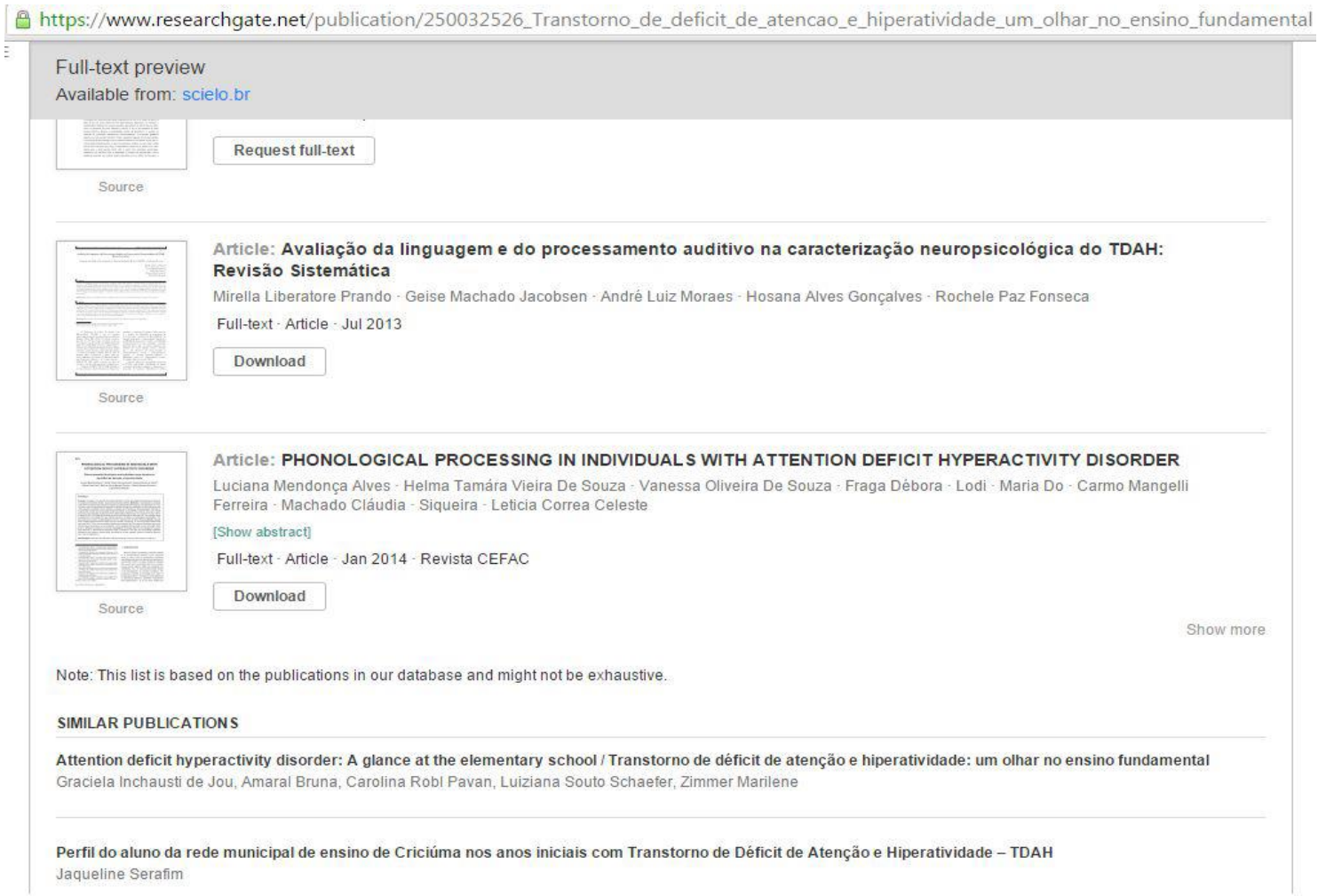

\section{Enunciado 6) ${ }^{7}$}

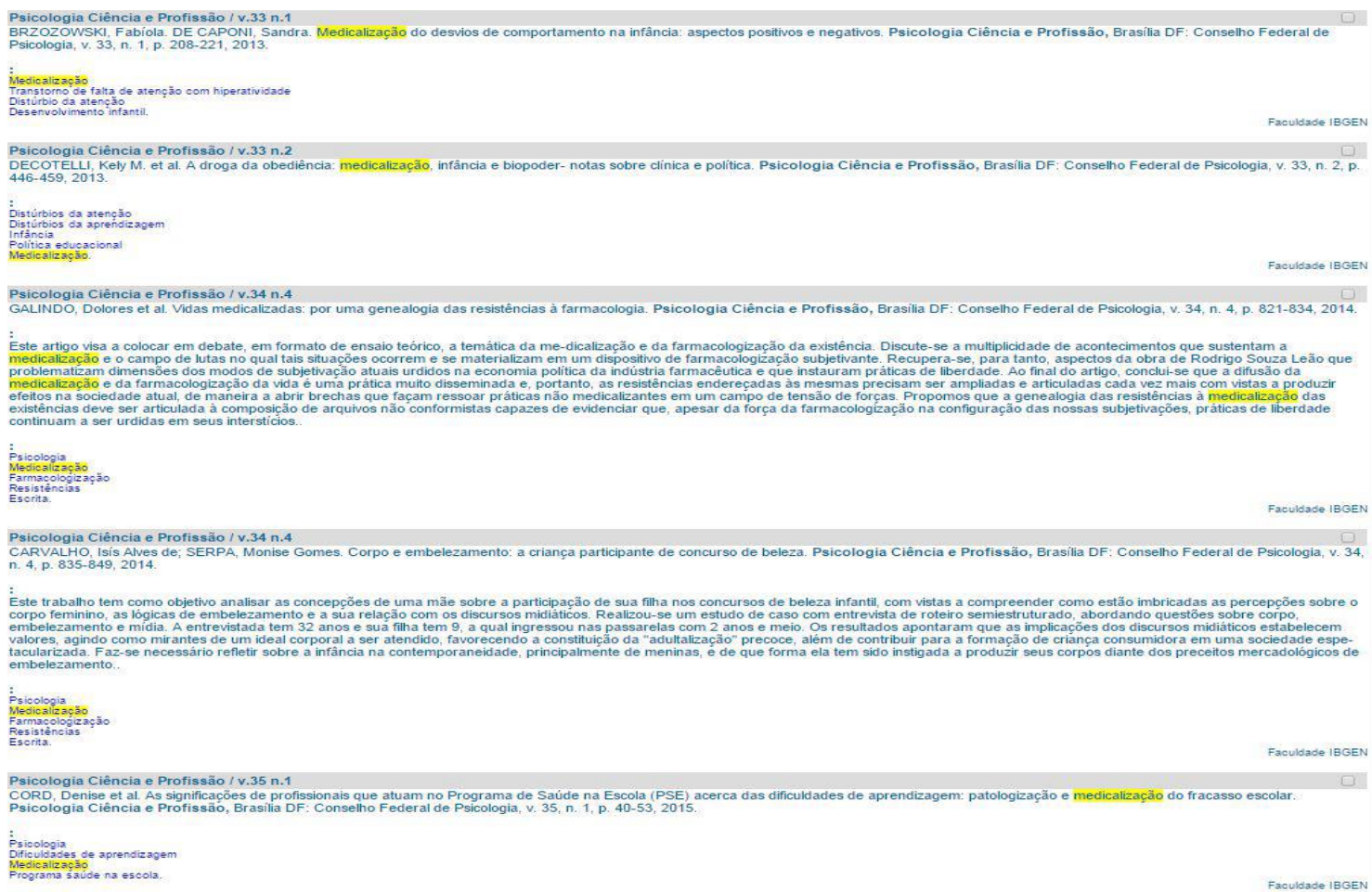

6 Disponível em: http://www.redalyc.org/articulo.oa?id=18815254005. Acesso em: 2 out. 2014.

7 Disponível em: http://www.redalyc.org/articulo.oa?id=282026452017. Acesso em: 2 out. 2014. 
No procedimento de descrição e de interpretação do funcionamento discursivo do Dispositivo de TDAH, analisamos os espaços de correlação desses enunciados tendo em vista a rede de artigos similares encontrada em cada uma das imagens coletadas, porque "é preciso saber a que se refere o enunciado, qual é o seu espaço de correlações, para poder dizer se uma proposição tem ou não um referente" (FOUCAULT, 2009, p. 102). Assim, observamos que nos seis enunciados há ligação do artigo analisado com as indicações de artigos que versam sobre o mesmo objeto: o TDAH.

Como já explicitado, a hipótese para a constituição do dispositivo reside na inter-relação das formações discursivas da Educação e da Saúde para a constituição do objeto TDAH naquilo que elas apresentam de semelhanças, dissemelhanças e de atravessamentos propiciados pelo funcionamento do campo associado. Dito isso, pautados em Foucault (2009), descrevemos e analisamos as regras de formação do objeto pelo regime de existência desses enunciados enquanto objetos discursivos.

Neste tópico, trabalhamos as relações discursivas que possibilitaram a formação de um objeto central - o TDAH - pela relação entre enunciados que abordam questões de diferentes ordens sobre esse Transtorno em um escopo que comporta enunciados da escola e das ramificações da Saúde. De modo análogo ao que expõe Foucault (2009), as relações aqui estabelecidas estão no domínio da interface entre o saber escolar e as multiplicidades do saber médico, uma vez que

\footnotetext{
são essas relações que, atuando no discurso psiquiátrico, permitiram a formação de todo um conjunto de objetos diversos. [...] Essa formação é assegurada por um conjunto de relações estabelecidas entre instâncias de emergência, de delimitação e de especificação. (FOUCAULT, 2009, p. 49),
}

Essas relações são observáveis em: 1) preditores farmacogenéticos do metilfenidato e análise de gene candidato à resposta de metilfenidato; 2) polimorfismos no gene transportador de dopamina, perfusão cerebral e genes dopaminérgicos em meninos, testes de desequilíbrio de transmissão do gene candidato relacionado à dopamina; 3) estudo de associação genômica no TDAH, candidatos genéticos mostram caminho para associações; 4) neurobiologia do TDAH e neuroanatomia estrutural e funcional do TDAH; 5) perfil do aluno da rede municipal de ensino de Criciúma nos anos iniciais com TDAH e avaliação da linguagem e do processamento auditivo na caracterização neuropsicológica do TDAH e 6) a droga da obediência; medicalização, 
infância e biopoder; as significações de profissionais que atuam no PSE acerca das dificuldades de aprendizagem; patologização e medicalização do fracasso escolar.

$\mathrm{Na}$ cartografia das práticas discursivas delineadas, confirmamos nossa hipótese acerca do objeto e do campo associado como elementos principais do funcionamento do dispositivo por meio dos elementos linguísticos que se mostram para nós quando da convergência dos discursos para um mesmo objeto e pela constituição de seu espaço de correlações. Isso porque os sujeitos discursivos nesses enunciados elegem o TDAH como referencial e, a partir dele, segundo suas práticas específicas, o decompõem, seja em seus aspectos relacionados à Saúde no âmbito da Farmacogenética, Genética, Neurobiologia e do Neurodesenvolvimento, seja no campo da Educação e da Psicologia.

O funcionamento discursivo das práticas elencadas respeita os princípios das regras impostas pela ordem do discurso, pelas condições de possibilidade e pela heterogeneidade constitutiva do discurso, uma vez que observamos diferentes perspectivas sobre um mesmo objeto, essas práticas descontínuas convergem, num dado momento, para o mesmo campo, que é a relação dos discursos da Saúde e da Educação quando tangenciam as questões da medicalização e da interferência do discurso médico no espaço escolar, como observado na enumeração anterior.

Ainda sobre as condições de emergência do objeto, procuramos analisá-lo, para além do acontecimento discursivo, no feixe de relações estabelecidas entre os enunciados, e tomamos como exemplo a Escola, a Genética e a Farmacogenética. A primeira, por encaminhar o aluno que foge ao padrão de comportamento esperado no espaço escolar à clínica, para que se possa obter um parecer médico sobre o que causa a agitação e/ou desatenção inerentes ao Transtorno. Já a segunda, como uma prática médica que objetiva o cérebro por meio do mapeamento dos genes no exercício de sua prática discursiva e, ao identificar anomalias nos genes DRD4, indica que pode haver indícios de hiperatividade; e a farmacogenética estuda os efeitos da intervenção medicamentosa nesses genes, sendo que essa última prática funciona como uma governamentalização do sujeito ao medicalizá-lo, visto que, segundo esses discursos, há algo que falha e que precisa ser corrigido.

Nesse sentido, observamos o esquadrinhamento do TDAH enquanto objeto de discurso, porque ele emerge nesse feixe complexo de relações dentro do próprio discurso médico e na intersecção com o discurso escolar que encaminha o aluno à clínica, onde o médico psiquiatra é o sujeito autorizado a instaurar a doença, legitimado 
pelos discursos patologizantes da genética, e com o medicamento proposto pela Farmacogenética.

É nesse movimento discursivo que constatamos a constituição do Dispositivo de TDAH, pela confluência desses diferentes discursos na formulação de um objeto central e de suas redes de discurso que formam uma constelação discursiva sobre esse objeto, as quais, por sua vez, constituirão outros dispositivos, outras redes discursivas. Nesse sentido, é possível identificar a regularidade enunciativa em meio à dispersão dos enunciados e, para além da descrição do objeto, procuramos também, nesse momento, descrever a constituição das práticas discursivas já citadas e cartografar como essas práticas constituem o Dispositivo de TDAH. Conforme Foucault (2009, p. 53),

relacionando-os [o enunciado e o objeto] ao conjunto de regras que permitem
formá-los como objetos de um discurso e que constituem, assim, suas
condições de aparecimento histórico; fazer uma história dos objetos
discursivos [...] que desenvolva o nexo das regularidades que regem sua
dispersão.

Assim, nessa série enunciativa, observamos que o objeto dos enunciados - o TDAH - é o que possibilita a emergência desse dispositivo, é o que diferencia os sujeitos do discurso que falam sobre ele, que produz o jogo discursivo a partir das diferentes posições assumidas pelos sujeitos e que trazem em si um discurso de verdade sobre esse objeto único e ao mesmo tempo tão díspar.

$\mathrm{Na}$ formação do objeto TDAH, concluímos que os enunciados analisados correspondem aos quatro princípios elencados por Foucault (2009): condições de emergência do objeto, campo de exterioridade e feixe de relações, relações primárias ou secundárias e relações discursivas e o discurso enquanto prática discursiva. As condições de emergência do TDAH observadas nos permitem analisá-las fundamentados no pensamento foucaultiano de que "não se pode falar de qualquer coisa em qualquer época" (FOUCAULT, 2009, p. 50), isso porque houve uma condição de possibilidade para que se pudesse acrescentar o Transtorno nos Manuais Diagnósticos. Semelhantemente, no próprio campo da Saúde, há diferenças quanto ao modo pelo qual se fala sobre o TDAH, tendo em vista as diferentes abordagens das práticas laboratoriais e clínicas que têm o TDAH como objeto maior de análise, com enunciados que circulam no domínio do campo associado ao avizinharem-se por semelhanças em suas práticas discursivas, mas também por se mostrarem opostas em outros tantos momentos.

Ainda sobre as condições de emergência do objeto, procuramos analisá-lo, para além do acontecimento discursivo, no feixe de relações estabelecidas entre os 
enunciados, e tomamos como referente a escola, a Genética e a Farmacogenética. A primeira, por encaminhar o aluno que foge ao padrão de comportamento esperado no espaço escolar à clínica, para que se possa obter um parecer médico sobre o que causa a agitação e/ou desatenção inerentes ao Transtorno. Já a segunda, como uma prática médica que objetiva o cérebro pelo mapeamento dos genes no exercício de sua prática discursiva e, ao identificar anomalias nos genes DRD4, indica que pode haver indícios de hiperatividade; e a farmacogenética estuda os efeitos da intervenção medicamentosa nesses genes, sendo que essa última prática funciona como uma governamentalização do sujeito ao medicalizá-lo, visto que, segundo esses discursos, há algo que falha e que precisa ser corrigido.

Nesse sentido, observamos o esquadrinhamento do TDAH enquanto objeto de discurso, porque ele emerge nesse feixe complexo de relações dentro do próprio discurso médico e na intersecção com o discurso escolar que encaminha o aluno à clínica, onde o médico psiquiatra é o sujeito autorizado a instaurar a doença, legitimado pelos discursos patologizantes da genética e com o medicamento proposto pela Farmacogenética. Sobre a constituição do objeto, Foucault $(2009$, p. 50) afirma que

o objeto não espera nos limbos a ordem que vai liberá-lo e permitir-lhe que se encarne em uma visível e loquaz objetividade. Ele não preexiste a si mesmo, retido por alguns obstáculos aos primeiros contornos da luz, mas existe sob condições positivas de um feixe complexo de relações.

Quanto ao campo de exterioridade e ao feixe de relações, reiteramos que as relações não se dão no objeto, mas sim entre os enunciados. $\mathrm{O}$ enunciado isolado do Neurodesenvolvimento não constitui o TDAH, porque, para que haja confirmação do Transtorno, é preciso que tenha a intervenção de um psicólogo escolar que primeiramente realizou o encaminhamento à clínica médica, assim "essas relações não estão presentes no objeto; não são elas que são desenvolvidas quando se faz sua análise" (FOUCAULT, 2009, p. 50), mas são essas relações que fazem emergir o objeto.

O terceiro elemento colocado por Foucault (2009) trata das relações primárias e secundárias estabelecidas entre os diferentes discursos. As primárias são compreendidas no âmbito institucional e das práticas relacionadas a esses espaços; as secundárias estão no plano do discurso. Todavia, essas relações não exprimem e sustentam diretamente o objeto de que falam, assim como a relação entre a família e a criminalidade no discurso psiquiátrico, tendo em vista que esta "não reproduz, sabemos bem, o jogo das 
dependências reais; mas não reproduz tampouco o jogo das relações que tornam possíveis e sustentam os objetos do discurso psiquiátrico" (FOUCAULT, 2009, p. 51).

A interpretação que aqui fazemos das relações estabelecidas entre os domínios cartografados para a constituição do objeto, a saber: 1) Genética, 2) Farmacogenética, 3) Neurodesenvolvimento, 4) Neurobiologia, 5) Psicologia e 6) Educação, reside nas condições de possibilidade para a emergência do TDAH, uma vez que se trata de observar e descrever a discursividade desse objeto pelo imbricamento entre esses seis domínios, considerando o fato de esses campos discursivos tratarem do TDAH em aspectos divergentes, mas, ao mesmo tempo, complementares e que o constituem. Como explica Foucault (FOUCAULT, 2009, p. 51), "o problema é fazer com que apareça a especificidade dessas últimas e seu jogo com as outras duas".

\section{As isotopias e os isomoformismos arqueológicos}

Para além desses apontamentos, observamos, nessa empreitada arquegenealógica do Dispositivo de TDAH, os isomorfismos arqueológicos (FOUCAULT, 2009, p. 181) presentes nesse dispositivo, considerando como um objeto pode ser formado por diferentes elementos discursivos: "a partir de regras análogas [...] mostrar entre formações diferentes, os isomorfismos arqueológicos”. Foi igualmente possível apresentarmos "o modelo arqueológico de cada formação" (FOUCAULT, 2009, p. 181), posto que demonstramos como a ordem do olhar e os registros escritos são aplicados ao processo de objetivação do hiperativo e da hiperatividade, mas não funcionam do mesmo jeito em suas práticas discursivas. Sobre

Identificamos ainda uma isotopia arqueológica quando observamos o funcionamento da Genética e do Neurodesenvolvimento, ambos do campo da Saúde, tendo o cérebro como objeto, mas com diferentes instrumentos e práticas para decompôlo, ou seja, "como conceitos perfeitamente diferentes [...] ocupam uma posição análoga na ramificação de seu sistema de positividade" (FOUCAULT, 2009, p. 181).

Nas defasagens arqueológicas, observamos esse movimento na governamentalidade do sujeito hiperativo com relação a algumas escolhas lexicais idênticas, mas que se diferem em suas práticas, tais como: tratamento e olhar. Para a escola, o tratamento está no campo do acompanhamento educacional especializado, e o olhar refere-se às questões comportamentais que servem para vigiar o sujeito no espaço escolar, como podemos verificar no enunciado 5, que traz um artigo sobre observações 
a propósito de alunos do Ensino Fundamental que possibilitam caracterizá-los como portadores do TDAH. Já para a Saúde, o tratamento reside nas práticas de medicalização, e o olhar recai em questões biológicas patologizantes, demonstrando que “como uma única e mesma noção (eventualmente designada por uma única e mesma palavra) pode abranger dois elementos arqueologicamente distintos" (FOUCAULT, 2009, p. 181), conforme verificamos com o uso de "medicalização", no enunciado 6, que expõe estudos sobre a medicalização para o que se considera desvio de comportamento infantil, e também estudos sobre a medicalização enquanto instrumento para a sustentação da indústria farmacêutica.

Por fim, na cartografia do Dispositivo de TDAH, demonstramos as correlações arqueológicas quando do estabelecimento de "relações de subordinação ou de complementaridade" (FOUCAULT, 2009, p. 182). Nos discursos da Educação, evidenciamos a subordinação ao discurso médico nas práticas higienistas, no espaço escolar, pela mediação de questões biológicas na Educação, para legitimar os discursos. Quanto à complementaridade, observamos esse movimento no discurso médico, nas redes discursivas que funcionam em conjunto, tais como: Genética e Farmacogenética, Neurodesenvolvimento e Neurobiologia; os primeiros, por lidarem com genes e medicamentos, os segundos, por questões orgânicas e fisiológicas do cérebro.

No esquadrinhamento da constituição do dispositivo e das práticas discursivas cartografadas, descrevemos a circulação dos discursos e a produção de sentido desses tendo em vista o fato de que o dispositivo é heterogêneo, estabelece laços em meio à dispersão dos enunciados e objetos envolvidos e acaba por manifestar em suas práticas o exercício do poder. Como explica Sargentini (2015, p. 23), "um dispositivo permanece porque ele se abre para um duplo processo: de sobredeterminação funcional e de perpétuo preenchimento estratégico".

Considerando esse funcionamento da ordem do olhar no processo de objetivação e de subjetivação do aluno hiperativo, justificamos a necessidade de discutirmos os dispositivos disciplinares para a constituição identitária desse sujeito, uma vez que o hiperativo é o sujeito que escapa das redes de poder nas instituições escolar e médica. Foucault (2006) discorre sobre a isotopia dos dispositivos de disciplina e de como eles se articulam para que o exercício efetivo do poder ocorra. Assim, constatamos que os dispositivos menores, ao convergirem para o objeto e o campo associado, possibilitam a emergência de um dispositivo maior. O Dispositivo de TDAH só é possível pela junção dos discursos da Educação e da Saúde e dos dispositivos que os constituem. 
Analisamos o aluno hiperativo como o sujeito que ultrapassa o que Foucault (2006) concebe por margens do poder disciplinar. Ao ultrapassar essa barreira, esse sujeito faz funcionar o Dispositivo de TDAH naquilo que diz respeito à necessidade do dispositivo de responder a uma demanda, a uma emergência discursiva, porque esse corpo anormal era, no princípio, inclassificável. Nesse movimento discursivo, observamos o poder disciplinar em exercício por meio do dispositivo de escrita que possibilitou a emergência dos Manuais Diagnósticos como um enunciado que baliza a prática discursiva da Psiquiatria. Sobre a isotopia, Foucault (2006, p. 66) explica que

os diferentes dispositivos devem poder se articular entre si. Por causa justamente dessa codificação, dessa esquematização, por causa das propriedades formais do dispositivo disciplinar, deve-se poder passar sempre de um a outro. É assim que as classificações escolares se projetam, sem muita dificuldade e mediante certo número de correções, nas hierarquias sociais técnicas que encontramos nos adultos.

Com o objetivo de analisar o processo de normatização e de normalização da conduta desse corpo anormal, descrevemos os enunciados observando as práticas de controle e de correção do aluno hiperativo no espaço escolar, considerando que o poder disciplinar tem por característica ser anomizante, ou seja, por um lado, evidencia o anormal e, por outro, procura meios de normalização. Foucault (2006, p. 68) explica que essa normalização é uma das características do poder disciplinar porque "um perpétuo trabalho da norma na anomia caracteriza os sistemas disciplinares".

Observamos que a mecânica do poder disciplinar, para Foucault (2009a), funciona de modo a normalizar os corpos. Para tanto, a estratégia compreende: a) fabricação e distribuição dos corpos sujeitados; b) individualização; c) vigilância; d) divisão; e) hierarquização; e f) homogeneização. Sobre os elementos elencados, verificamos a fabricação e a distribuição do sujeito aluno hiperativo no momento em que há a divisão do TDAH em três aspectos: déficit de atenção, hiperatividade e impulsividade, sendo os sintomas listados separadamente, com a indicação de que são inadequados e que causam prejuízos significativos diagnosticados clinicamente.

\section{Conclusão}

Ao cartografarmos as especificidades das práticas discursivas da Educação e da Saúde foi possível, em cada particularidade dessas práticas, identificarmos o dispositivo de escrita como um elemento discursivo para a constituição dos saberes sobre o aluno hiperativo. Identificamos, também, os isomorfismos arqueológicos (FOUCAULT, 
2009) no Dispositivo de TDAH que se relacionam aos modos pelos quais a ordem do olhar e da escrita funcionam de diferentes formas nas práticas discursivas cartografadas.

Nessa cartografia, analisamos que um dispositivo se forma quando da intersecção do campo associado e do objeto, os quais, em conjunto com os sujeitos e as instituições, apresentam as condições de possibilidade para a produção de discursos sobre determinado objeto. No caso do Dispositivo de TDAH, a junção dos domínios discursivos da Educação e da Saúde se inter-relacionam no campo do objeto, uma vez que os sujeitos (do campo escolar e do campo da saúde) e as instituiçõos (escola, clínica, hospital) tomam o TDAH e o aluno hiperativo como objeto de saber.

Dito isso, para que o Dispositivo de TDAH pudesse se constituir enquanto tal, cartografamos, também, os dispositivos disciplinares que estão imbricados no processos discursivos de produção de saberes sobre o TDAH e sobre o aluno hiperativo e que sustentam os sujeitos e as instituições que tratam desse sujeito da educação.

Considerando que um dispositivo responde a demandas discursivas, para um dispositivo se formar e produzir discursos, é preciso descrever os mecanismos disciplinares que possibilitam a produção de discursos. Cartografamos os micro dispositivos da Educação e da Saúde, que, em seus regimes de verdade e em suas relações de saber-poder, com suas especificidades disciplinares nas ordens do olhar, da escuta e da escrita, dão sustentação ao dispositivo macro do TDAH.

\section{REFERÊNCIAS}

DELEUZE, G. Um novo arquivista (Arqueologia do Saber). In: Foucault. Trad. Claudia Sant'Anna. Paulo: Martins, 1988.

O que é um dispositivo. In: Michel Foucault filósofo. Trad. Wanderson Flores do Nascimento. Barcelona: Gedisa, 1996, p. 155-161.

DREYFUS, H.; RABINOW, P. Michel Foucault, uma trajetória filosófica: para além do estruturalismo e da hermenêutica. Trad. Vera Portocarrero e Gilda Gomes Carneiro. 2. Ed., rev. Rio de janeiro: Forense Universitária, 2010.

FOUCAULT, M. O olho do poder. In: A Microfísica do poder. Trad. Roberto Machado. Rio de Janeiro: Editora Graal, 1977a, p. 107-125

Sobre a história da sexualidade. In: A Microfísica do poder. Trad. Roberto Machado. Rio de Janeiro: Editora Graal, 1977b, p. 243-276.

2006.

O poder psiquiátrico. Trad. Eduardo Brandão. São Paulo: Martins Fontes, 
A Ordem do Discurso. Trad. Laura Fraga de Almeida Sampaio. 18. ed. São Paulo: Edições Loyola, 2008.

A Arqueologia do Saber. Trad. Luiz Felipe Baeta Neves. Rio de Janeiro: Forense Universitária, 2009.

Os Anormais: curso no Collège de France. Trad. Eduardo Brandão. São Paulo: WMF - Martins Fontes, 2011.

Aulas sobre a vontade de saber: curso do collège de France. Trad. Rosemary Costhek Abílio. São Paulo: WMF Martins Fontes, 2014.

GUILHAUMOU, J.; MALDIDIER, D. Efeitos do arquivo. A análise do discurso no lado da história. .In: ORLANDI, Eni Puccinelli (Org.). Gestos de leitura: da história no discurso. 2. ed. Campinas: Editora da Unicamp, 1997.

KOCH, I. G. V. Desvendando os segredos do texto. São Paulo: Cortez, 2005.

LARROSA, J. “Tecnologias do eu e educação”. In: Silva, Tomaz Tadeu. O sujeito da educação. Petrópolis: Vozes, 1994, p.35-86.

SARGENTINI, V. Dispositivo: um aporte metodológico para o estudo do discurso. In: SOUSA, K. M.; PAIXÃO, H. P. (Org.). Dispositivos de poder/saber em Michel Foucault: biopolítica, corpo e subjetividade. São Paulo: Intermeios, 2015, p. 19-36. 